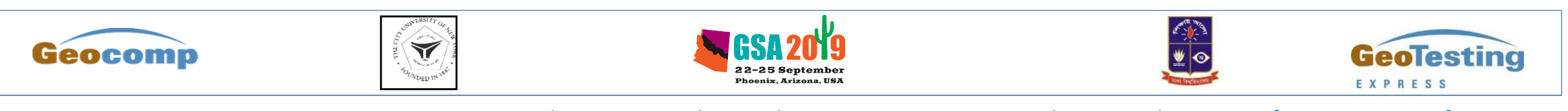

Paper No. 299-12, T150. Advances in Understanding Processes at or Near the Groundwater-Surface Water Interface 25 September 2019: GSA Annual Meeting in Phoenix, Arizona, USA - 2019, Geological Society of America Abstracts with Programs. Vol. 51 , No. 5

\title{
AN ENGINEERING GEOLOGICAL ANATOMY
} OF THE PADMA RIVER BANK FAILURE AND EROSION, 2018: A CASE STUDY OF NARIA BANK SECTION, BANGLADESH

Mir Fazlul Karim, Geocomp Corp/GeoTesting Express Inc., USA (Ex-Director, Geol. Survey of Bangladesh)

Nazrul I. Khandaker, Earth and Physical Sciences, York College (CUNY), USA Shahidul Haque, Consultant, Municipal Engineering, Ontario, Canada,

M. Zillur Rahman, Department of Geology, University of Dhaka, Bangladesh, Dhaka, 1000, Bangladesh, Muhammad Qumrul Hassan, Department of Geology, University of Dhaka, Bangladesh

ASM Maksud Kamal, Department of Disaster Science and Management, University of Dhaka, Bangladesh Masud Ahmed, New York City Department of Environmental Protection, Geotechnical Section, New York, USA and

Belal A. Sayeed, Dewberry Geotechnical Company, New York, USA Contacting Author geologist.karim@gmail.com 


\section{AN ENGINEERING GEOLOGICAL ANATOMY OF THE PADMA RIVER BANK FAILURE AND EROSION, 2018: A CASE STUDY OF NARIA BANK SECTION, BANGLADESH}

ABSTRACT : The Naria town of Bangladesh is developed on the right bank of the Padma River. The bank is an old natural levee of Meghna River. The Holocene-Recent geology of Naria is actively dominated by the fluvial processes of Ganges-Brahmaputra-Meghna River system where the deltaic sediments are characterized as unconsolidated fine sand and silt, covered by thin veneer of clayey silt and loam. The annual volume of water discharge and flow dynamics are dependent on the intensity of the rainfall, runoff and the length of dry winter. Excessive river bank erosion, channel avulsion, renewed submergence of floodplains, and formation of natural levees and channel-bars are due to natural geomorphological processes that impact the area by inevitable ground failures. The geological attributes of ground condition and drastic variations in water levels make the area extremely vulnerable to severe bank failures and erosion.

A unique erosion phenomenon prevailing in this part of Bengal delta prompted this study. During Aug-Sept, 2018 a sudden complex attenuation of current, wave and vortex in the Padma water flow caused an extraordinary disaster and made more than 5000 people homeless overnight by devouring away houses including concrete buildings, factories and markets. It is observed that geologically the Padma River remained confined within a width of 5 miles striking NW-SE trend following the margins of older alluvium and Faridpur Trough. The river tends to a meandering pattern consisting of deep vertical trenches along the Naria curvature. The deep trenches form along right bank and render the ground increasingly more vulnerable to subaqueous slope failure due to presence of thick ( $200 \mathrm{ft}$.) alternating crossbedded silt and micaceous fine sand of very high dilatancy and low angle of friction.

The present study identifies some application of technological advancement for developing real-time engineering geological mapping systems for monitoring and managing complex river bank erosion. Large scale 3D engineering geological map coupled with air-borne photogrammetric and radar inferrometry methods can be applied for real-time monitoring and prediction of differential settlements, subaqueous failures and ground movement. The point cloud maps developed using data from these systems can refine engineering geological maps for decision makers and improve the design of protective measures and sustainable engineering structures.

GSA Annual Meeting in Phoenix, Arizona, USA - 2018, Paper No. 299-12, T150. Advances in Understanding Processes at or Near the Groundwater-Surface Water Interface doi: 10.1130/abs/2019AM-335679 


\section{Background and Objectives}

This presentation is on last year's (2018) river erosion along Padma R, near Naria with possibilities of preparation of engineering geological maps and database.

The simple geological maps or conventional geotechnical investigations (both field and laboratory) do not provide right directions for river bank hazard prediction or bank failure risk management in the unique fluvial environs of the Bengal delta.

Because geotechnical samples are not truly representative of actual field condition and can be of misleading in the uses.

That is the reason it necessary to illustrate presence and influence of sedimentary structures. It is better if we can investigate and understand bank cliff erosion phenomena in and around Naria for a long-term understanding and design of required geostructures and disaster management plan. 


\section{Ganges R}

IN D I A

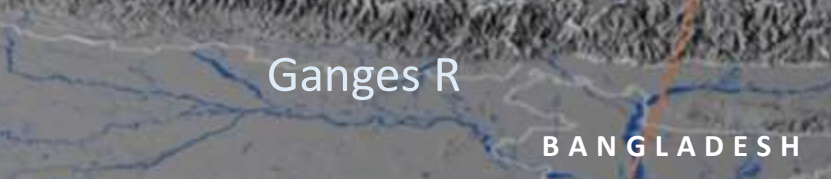

$$
\text { Padma }
$$

Bay of Bengal
During Aug-Sept, 2018 a sudden complex attenuation of current, wave and vortex in the Padma water flow caused an extraordinary disaster and made more than 5000 people homeless overnight by devouring away houses including concrete buildings, factories and markets.

A unique erosion phenomenon prevailing in this part of Bengal delta prompted this study. young and longest in comparison to any other major rivers of the world.

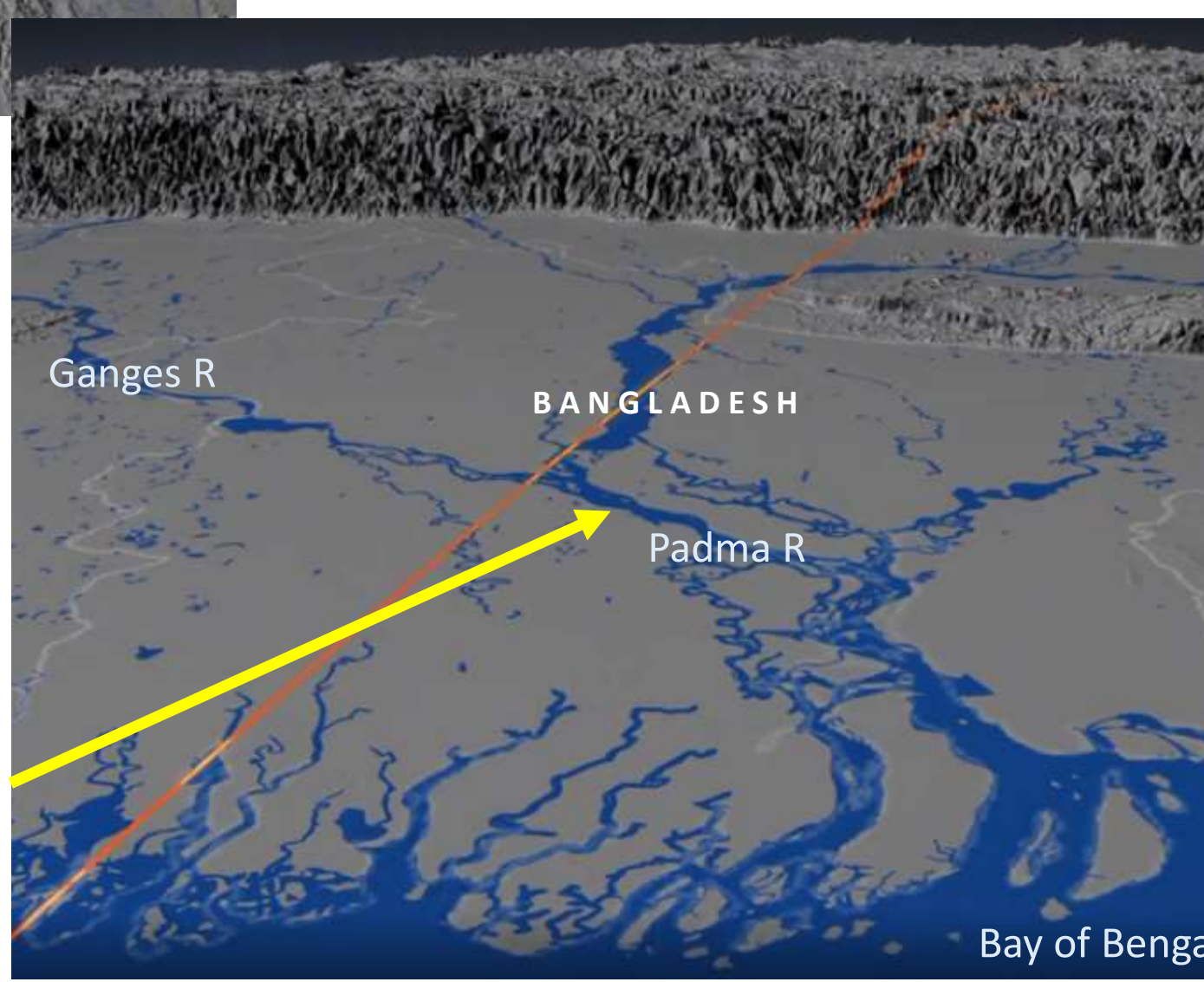


The furious Padma River at her bank full water stage

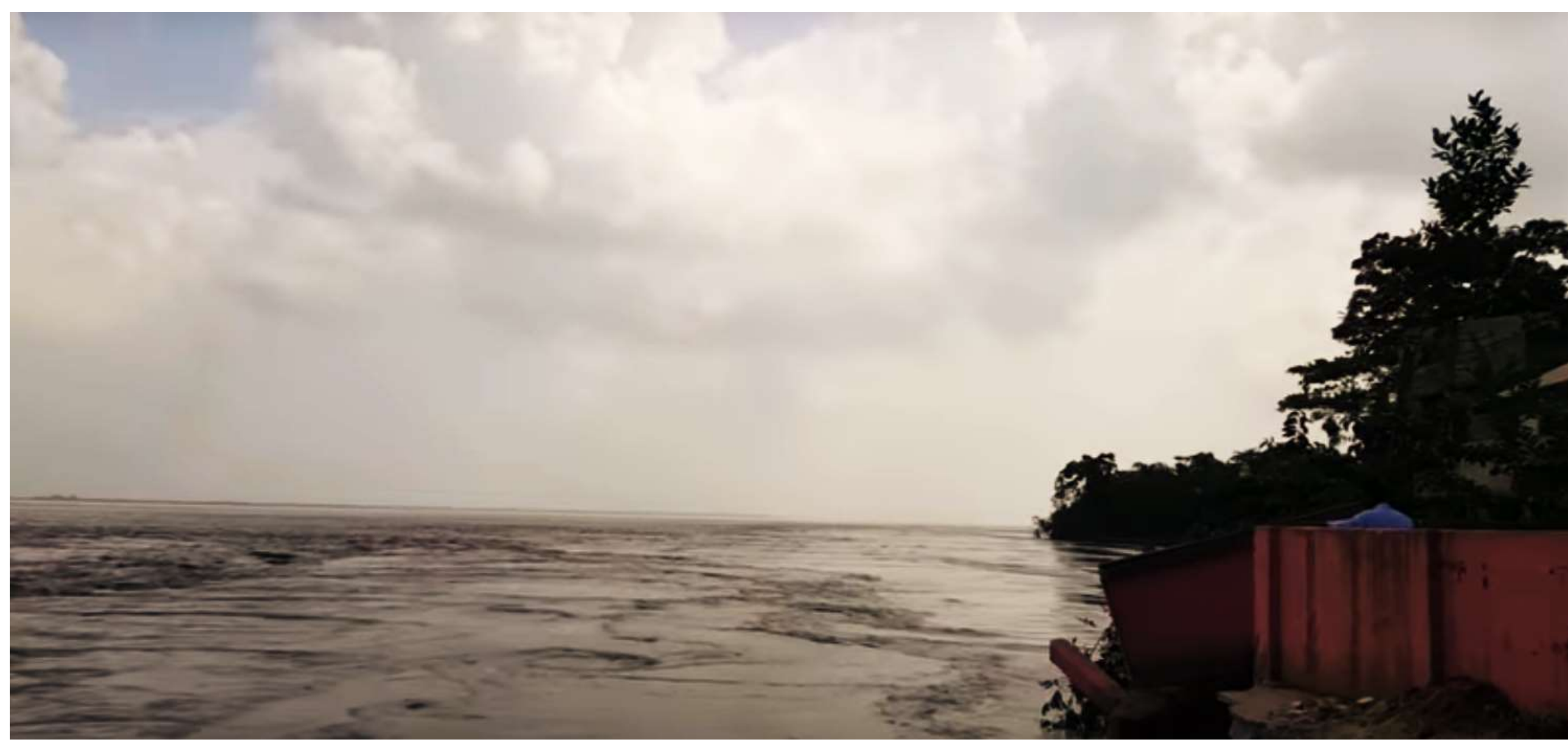




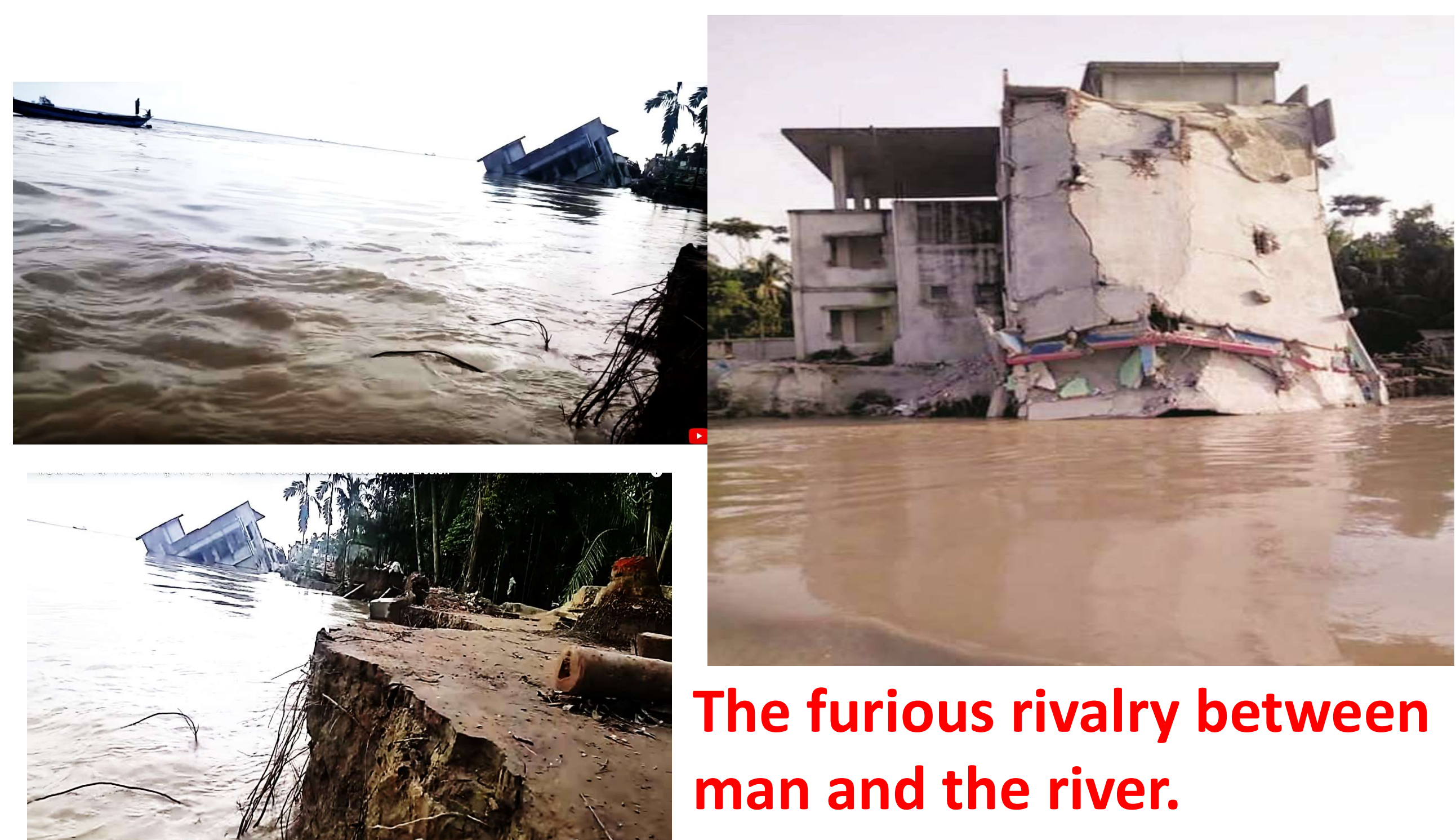




\section{Live River Shifting Observation for Live Geological Map Update System discussed later}




\section{Temporal Erosion Pattern of Padma \\ River Between Mawa and Chandpur}

\section{4 to 2016}

i Google Earth Imagery processed by Mir Fazlul Karim, Geocor To investigate geological causes of If that made 5000 people homeles.

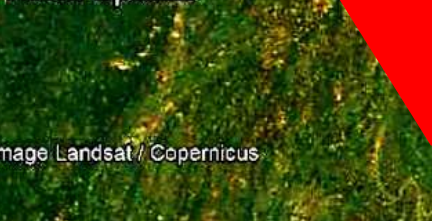


The

Consequences
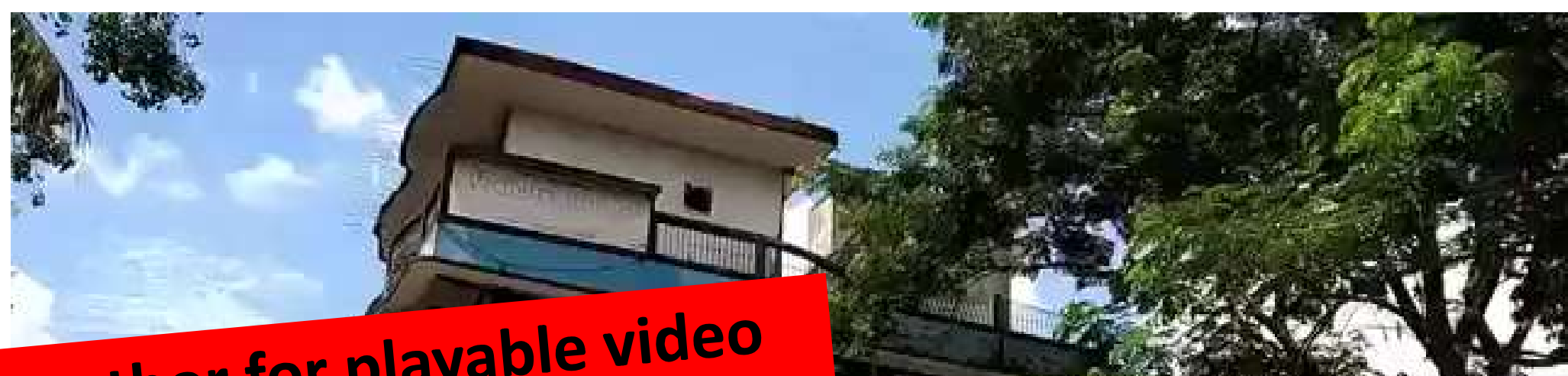

Please contact author for playable video mfkarimazad@gmail.com

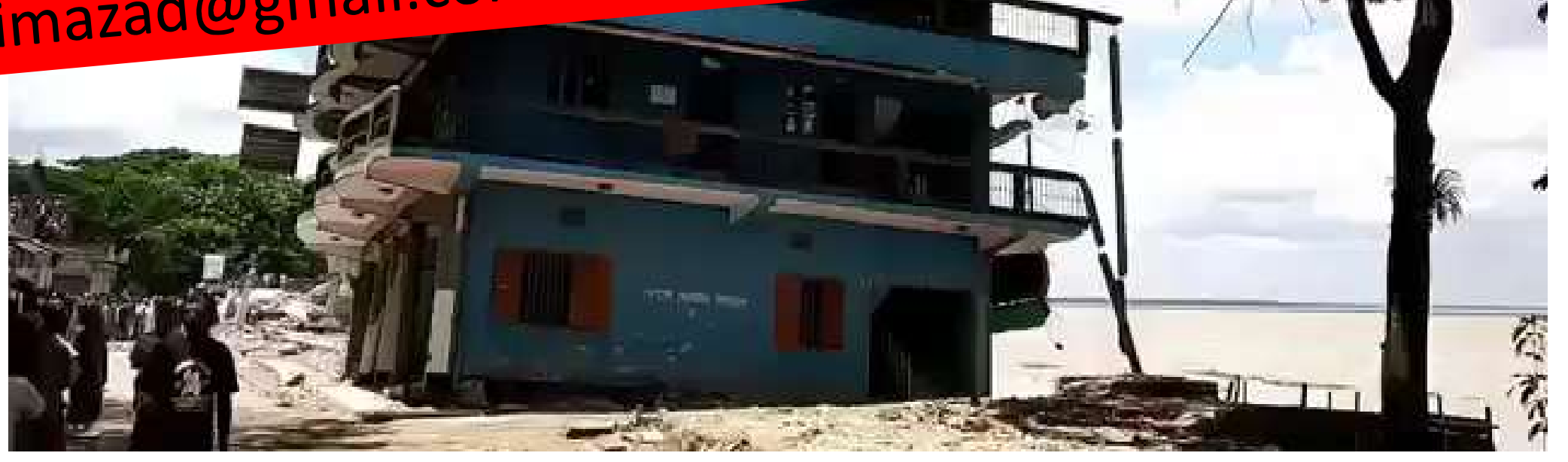

Play Video 

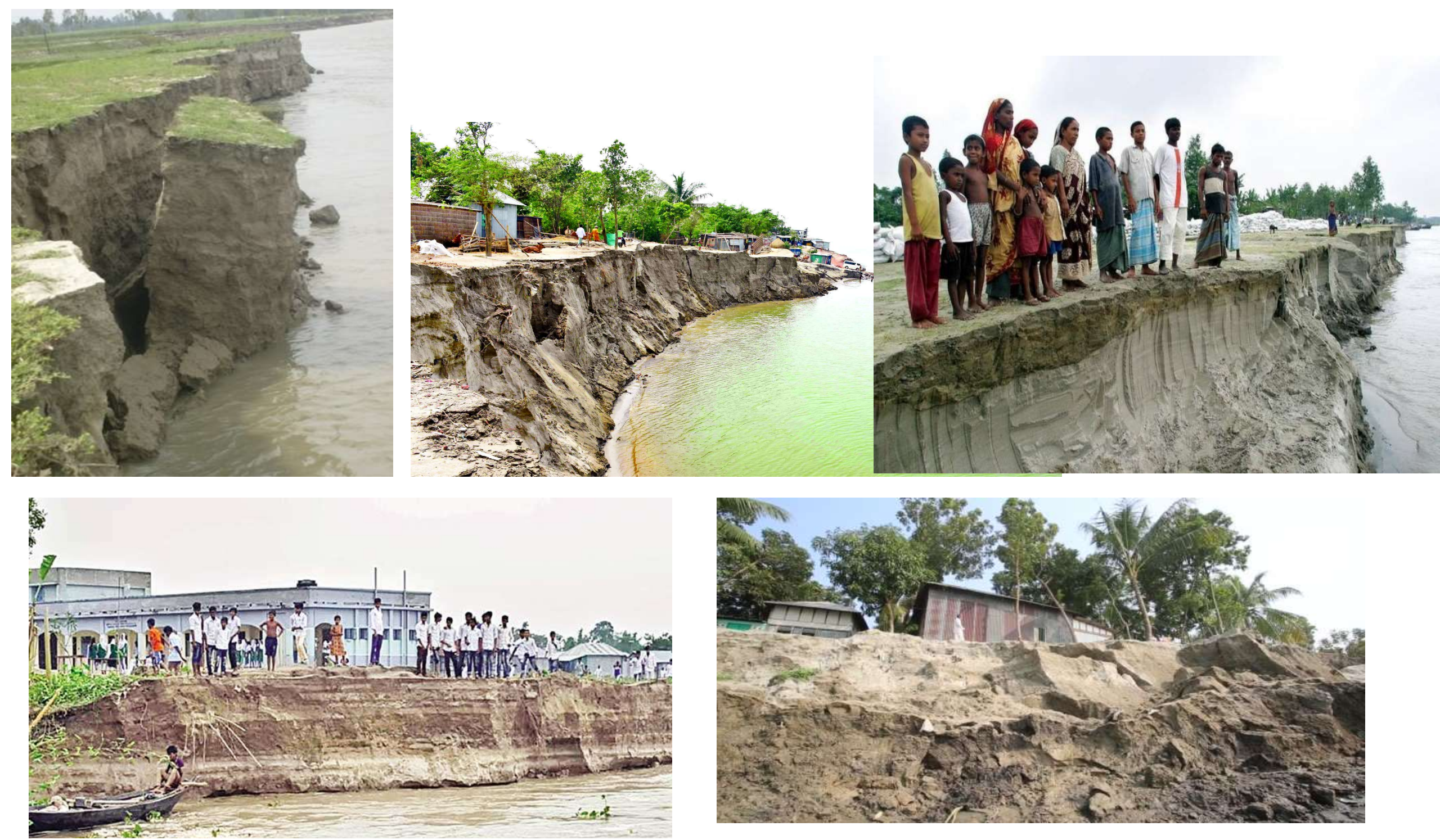
Geology and Tectonics 


\section{SURFACE GEOLOGY}

Tectonic Map of Bangladesh and surrounding areas

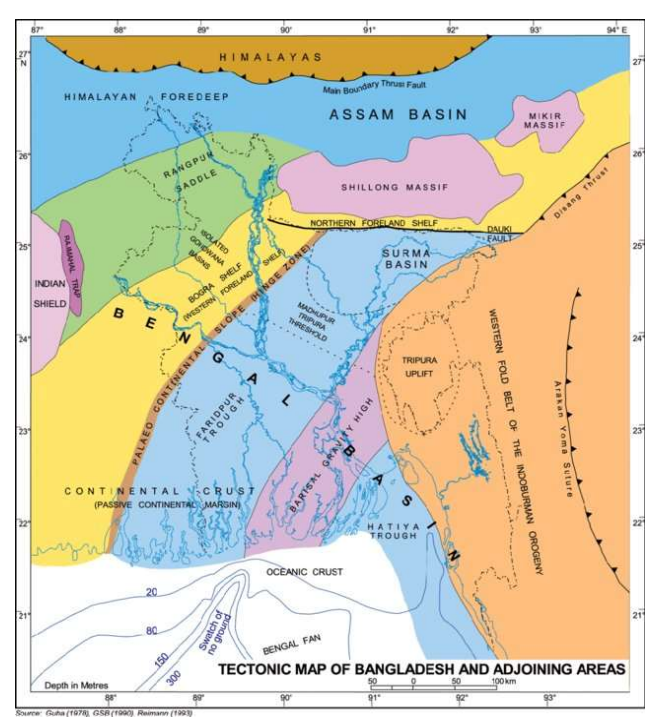

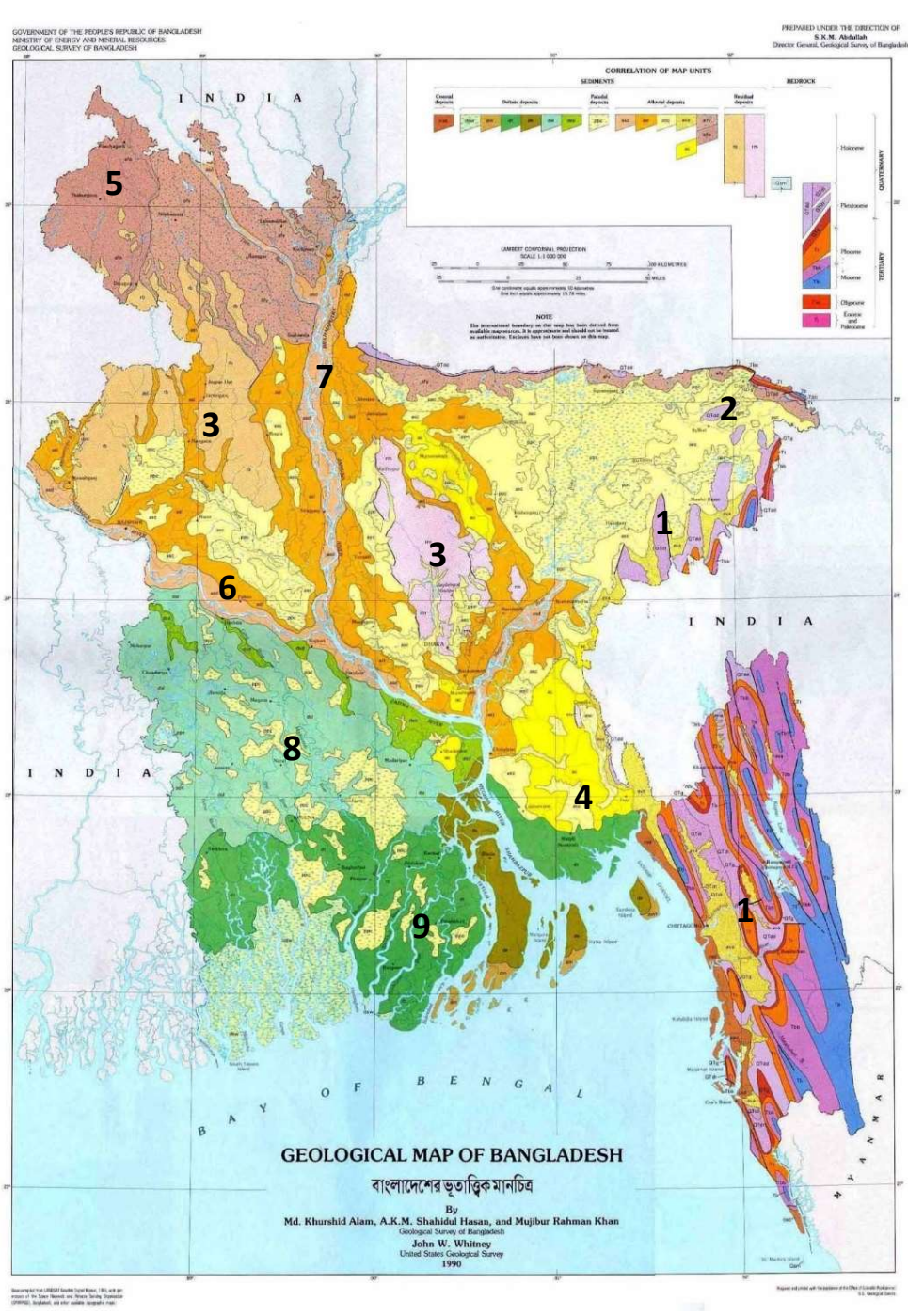

\section{Lithological Units}

\section{1 and 2}

Folded hills of Tertiary sedimentary rock 3

Pleistocene Terraces

Barind and Madhupur

4

Old Alluvial Deposit (Chandina Alluvium)

5

Alluvial Fan Deposit6

Paludal Deposit

Marshy clay \& peat

7

Young Alluvial

Deposit (Inter-stream deposit)

8 and 9

Deltaic and Coastal Deposit.

Including Beach, Estuarine and Mangrove swamp deposits. 


\section{Geomorphologic Map of Naria}
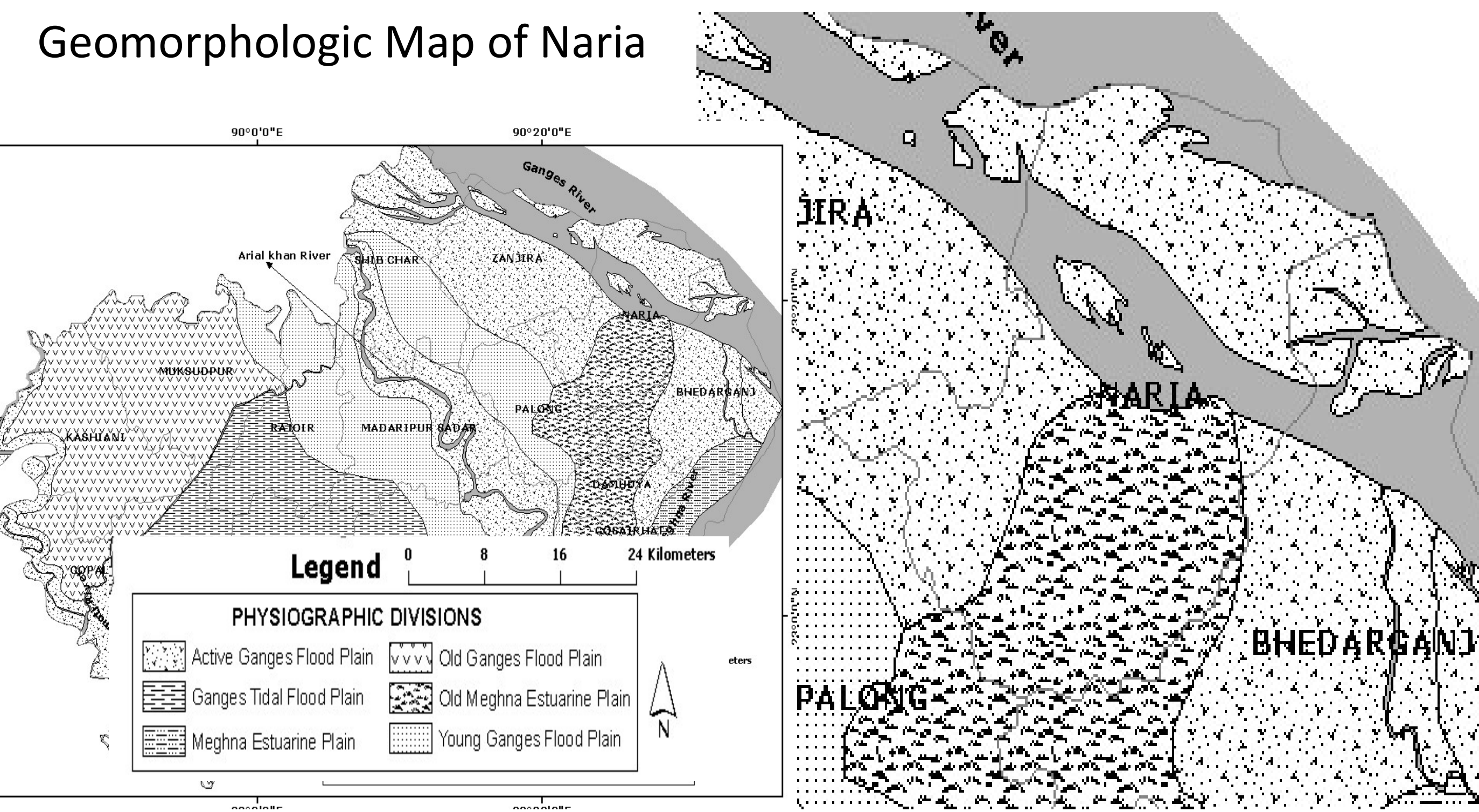


\section{Sub-Surface Geology}

The Holocene-Recent geology of Naria is actively dominated by the fluvial processes of Ganges-Brahmaputra-Meghna River system where the deltaic sediments are characterized as unconsolidated fine sand and silt, covered by thin veneer of clayey silt and loam.

\begin{tabular}{|c|c|c|c|c|c|}
\hline & & & & $\begin{array}{l}\text { LOCATION (Borehole-14) } \\
\text { Purbanaodoba union,Zazira upazila, Sariatpur District } \\
\text { LATITUDE-23.40978 } \\
\text { LONGITUDE- } 90.28343 \\
\text { TOTAL DEPTH }-57 \mathrm{~m}\end{array}$ & \\
\hline$\overline{\mathrm{p}(\mathrm{ft})}$ & Bottom(ft) & Top(m) & Bottom(m) & Lithological Description & Depositional environment \\
\hline 0 & 3 & 0 & 1 & Filling materials & \\
\hline 3 & 11 & 1 & 3 & $\begin{array}{l}\text { Sandy silt:Light olive grey }(5 Y 6 / 2) \text { and pale olive }(5 Y 6 / 3) \text {,staining along } \\
\text { roottubes which is very dark grey }(10 \mathrm{YR} 3 / 1) \text {,yellowish brown(10YR5/6),yellowish } \\
\text { brown(10YR5/4) and olive brown }(2.5 Y 4 / 4) \text {, laminated. }\end{array}$ & Flood basin \\
\hline 11 & 70 & 3 & 21 & $\begin{array}{l}\text { Sand:Grey }(7.5 Y R N 7 /) \text { and light grey(7.5YRN6/),fine with medium, huge mica, } \\
\text { micas are partially decomposed. }\end{array}$ & Channel \\
\hline 70 & 90 & 21 & 27 & $\begin{array}{l}\text { Sand with little silty clay:Grey(7.5YRN6/),very fine to fine with medium,huge } \\
\text { mica,micas are partially decomposed, few large mica flakes,few zill/roottubes, } \\
\text { silty clay is grey(5Y5/1),zill/roottubes present,laminated,burrows filled with sand } \\
\text { huge wood cut and vegetal matter found(89-90)ft. }\end{array}$ & Tidal/Bar top \\
\hline 90 & 187 & 27 & 57 & $\begin{array}{l}\text { Sand:Grey(7.5YRN6/), medium to fine,huge mica,micas are partially decomposed } \\
\text { interlaminated vegetal matter,wood debris found at } 165 \mathrm{ft} \text { and } 185 \mathrm{ft} \text {,lower part is } \\
\text { fine to medium with coarse. }\end{array}$ & Channel \\
\hline
\end{tabular}




\section{Sub-Surface Geology}

\begin{tabular}{|cccc|}
\hline Top $(\mathrm{ft})$ & Bottom $(\mathrm{ft})$ & Top $(\mathrm{m})$ & Bottom $(\mathrm{m})$ \\
\hline 0 & 5.5 & 0.0 & 1.7 \\
\hline 5.5 & 8 & 1.7 & 2.4 \\
8 & 11 & 2.4 & 3.4 \\
\hline
\end{tabular}

\begin{tabular}{|llll}
\hline 11 & 41 & 3.4 & 12.5 \\
& & & \\
\end{tabular}

\begin{tabular}{|c|c|c|c|}
\hline 41 & 66 & 12.5 & 20.1 \\
\hline 66 & 71 & 20.1 & 21.6 \\
\hline 71 & 76 & 21.6 & 23.2 \\
\hline 76 & 84 & 23.2 & 25.6 \\
\hline 84 & 97 & 25.6 & 29.6 \\
\hline 97 & 130 & 29.6 & 39.6 \\
\hline 130 & 161 & 39.6 & 49.1 \\
\hline 161 & 232.5 & 49.1 & 70.9 \\
\hline 232.5 & 236.0 & 70.9 & 72.0 \\
\hline
\end{tabular}

\section{Filling materials}

Bilashpur mouza,Bilashpur union,Zazira upazila, Sariatpur District

LATITUDE-23.31827

LONGITUDE- 90.37863

TOTAL DEPTH- $72.0 \mathrm{~m}$

Lithological Description

Depositional environment

Silty clay:dark grey(N5/) and bluish grey(5B5/1), sticky,soft,vegetal matter partly decomposed,little humic odour and laminated. No vegetal matter at ( $7 \mathrm{ft}-8 \mathrm{ft})$.

Silty clay:olive grey $(5 \mathrm{Y} 5 / 2)$ and light olive grey,sticky,soft,laminated,staining along roottubes pale olive (5Y6/3), light olive brown $(2.5 Y 5 / 6)$ and brown $(7.5 Y R 4 / 4)$, few shell present at $10.5 \mathrm{ft}$.

Interlayering of silt,silty sand,silty clay and sand: Silt is grey(5Y5/1),laminated

Silty sand is grey(7.5YR N5/), huge mica micas are partially decomposed, fine to very fine.sand is grey (5YR N5/) and very fine to fine. silty clay is grey(5Y5/1)and light olive grey(5Y6/2), sticky, soft and laminated.

Sand: Grey (7.5YR N5/), upper cycle is fine to very fine up to $41 \mathrm{ft}-56 \mathrm{ft}$ )

lower part is coarse to medium sand,grey $(5 \mathrm{~B} 5 / 1)$ and bluish grey $(5 \mathrm{~B} 5 / 1)$.huge

mica and micas are partially decomposed, wood debris found at $60 \mathrm{ft}$ and $63 \mathrm{ft}$.

Silt with clayey silt: Greenish grey(5B5/1), laminated (upper part clayey silt).

Sand: Bluish grey (5B 5/1), medium to coarse, few large mica flakes, huge mica and

few vegetal matter.

Clayey silt and silt: Clayey silt is dark grey(N4/),laminated up to $79 \mathrm{ft}$. Silt is bluish grey $(5 \mathrm{~B} 5 / 1)$ and laminated.

Interlayering of silty clay and sand: Grey (2.5Y N5/) and bluish grey(5B5/1)

coarse to medium, few mica.(Pektin found at $92 \mathrm{ft})$. Silty clay is dark grey(N4/) and

bluish grey(5B5/1), soft,sticky,few vegetal matter and laminated.

Sand:Light bluish grey (5B6/1)upper part is very fine to fine and lower part

is fine to medium with little coarse, few vegetal debris

Interlayering of sand and Clayey silt:Sand is bluish grey(5B5/1), dark grey(N4/),

fine to medium with coarse,huge mica, micas are partially decomposed,interlaminated vegetal matter.clayey silt is bluish grey(5B5/1),laminated.

Sand:Dark grey(N4/), grey(5Y6/1), huge vegetal debris, upper part is very fine to fine with medium and lower part is coarse to medium with pebbles, wood debris.

Silty clay:Dark grey(2.5YN3/) and bluish grey(5B5/1), sticky, hard, vegetal matter soapy felling,impregnated lithic granules, compact.

Inter tidal

Flood basin

Bar top

Channel

Tidal flood 


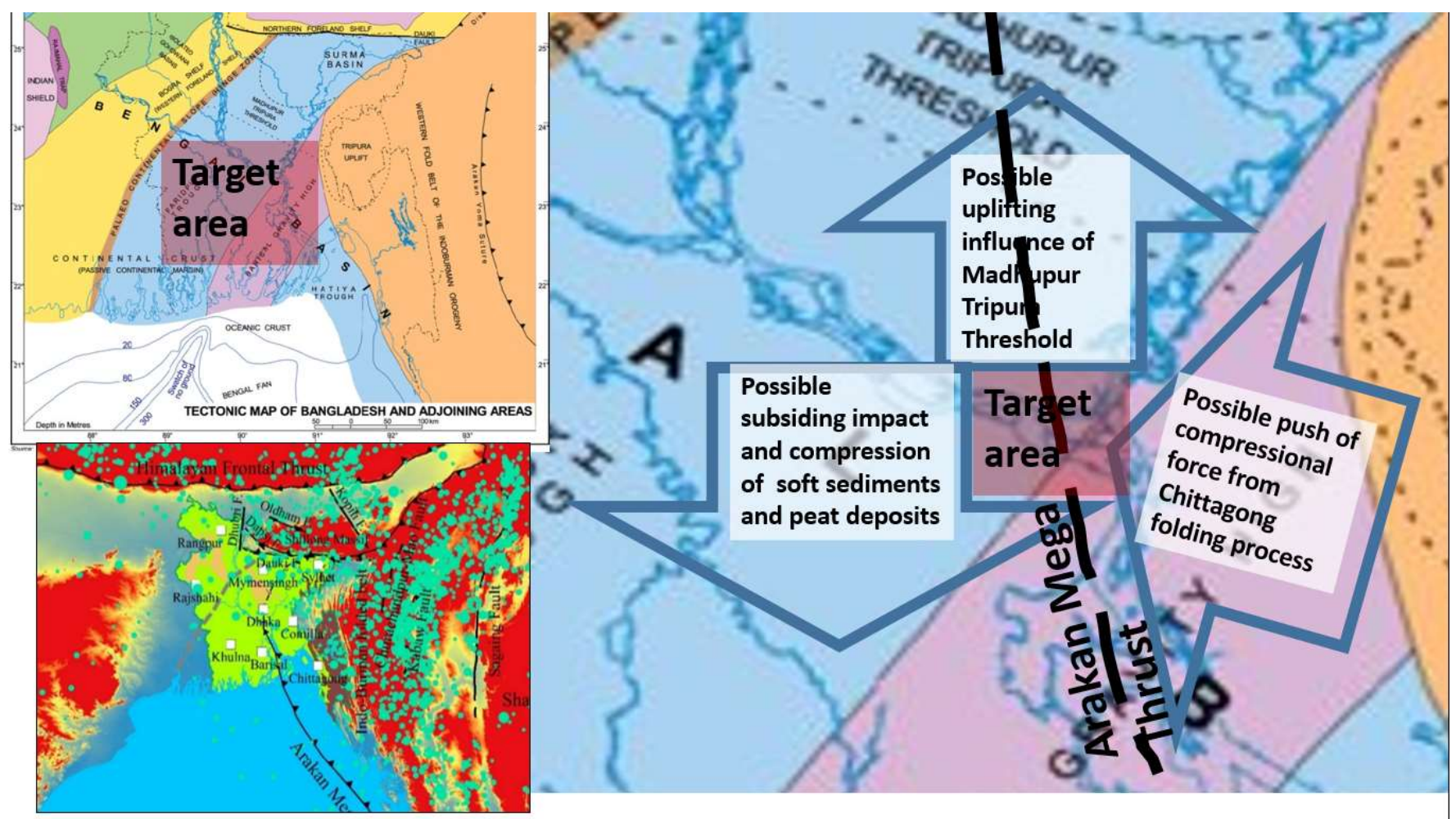

Possible impact of tectonic structural elements and dynamic forces rendered by tectonic movement and regional stratigraphic setting.

The Padma River Bank erosion or slope failures in the target area are influenced by complex act of tectonic shift and movement due to the junctural influence of multiple tectonic elements. The river erosion consists of two processes: basal erosion due to fluvial hydraulic force and bank failure under the influence of gravity and tectonic forces. 


\section{The exposed bank materials}

Top soil: 2-3 ft:

Brownish gray loamy soil or plough soil, mostly moist to dry, moderately permeable, fractured, Contains rootlets and perforations.

Below topsoil:

Sand: Gray and light gray, fine with medium, highly micaceous, laminated with fine silt, cross bedded, mostly rounded quartz, loose sand. 


\section{Padma River Bank failure Characteristics}

Generally the bank resistance strength varies with the degree of saturation of bank material.

The probability of bank failure is dependent on the stability characteristics of the river bank. (it can be both natural and man-made).

Where the degree of saturation of bank material is directly related to the variations of the river stages.

The magnitude and the frequency of bank failure is always related to the frequency and time span of the flooding.

The rate of bank erosion is related to basal erosion, material consistency, sedimentary structures and their discontinuity or the continuity pattern, and bank failure occurrences..

A method for measuring the rate of bank erosion and bank failure processes for the rivers like Padma is not appropriately performed or analyzed. The water discharge and the effects of hydraulic factors, bank geometry, properties are unique and never been modeled or tested. 
$23^{\circ} 26^{\prime} 01.14^{\prime \prime} \mathrm{N} 90^{\circ} 19^{\prime} 37.98^{\prime \prime} \mathrm{E}$

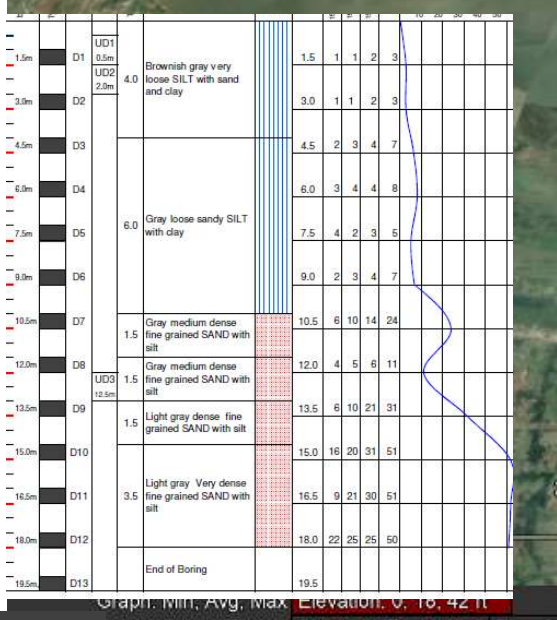

A

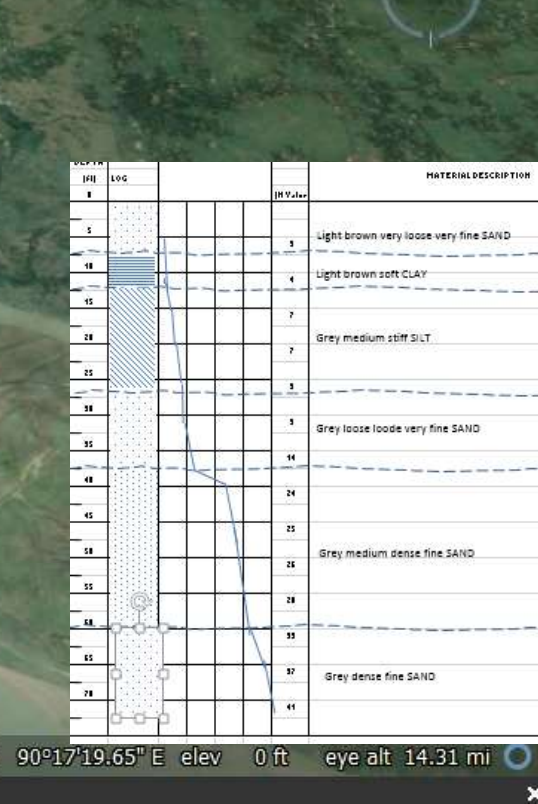

Imagery Dates $1 / 24 / 2019 \quad 23^{\circ} 26^{1} 41.13^{\mathrm{N}} \mathrm{N} \quad 90^{\circ}$

$42 \mathrm{f}$

42
25
0
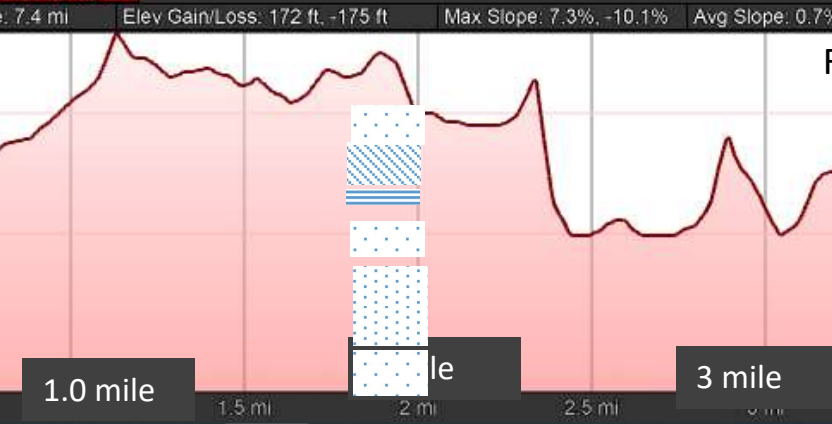

Flood water

A

(1)

A

Alternating cross-bedded silt and micaceous fine sand of very high dilatancy and low angle of friction due to presence of micaceous sand.

Right Bank

Left Bank 


\section{Development of bank failure processes}
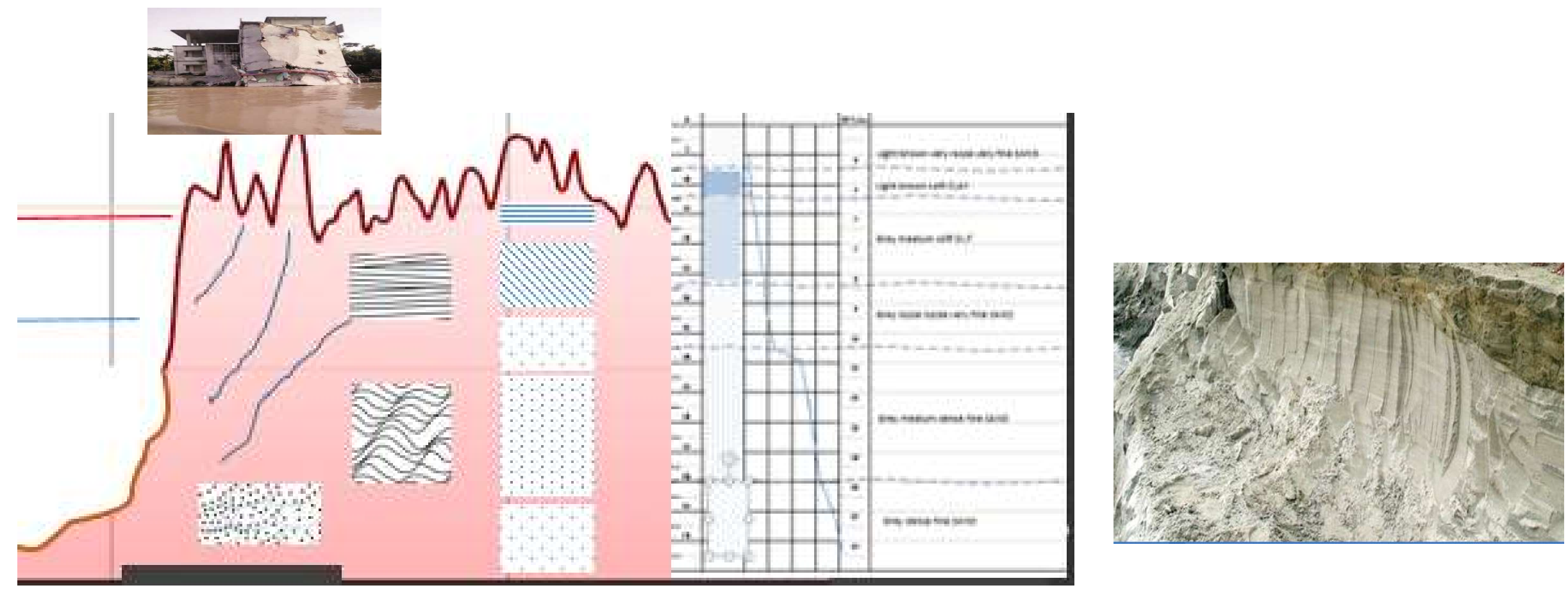

Preexisting fractures, inconsistent lithology, Hydrodynamic characteristics like Permeability and drastic changes in pore water pressure (PWP) including negative PWP, due to agricultural landuse and fall and rise of river water stages bank failure processes are evolved. 


\section{Geotechnical Characteristics}
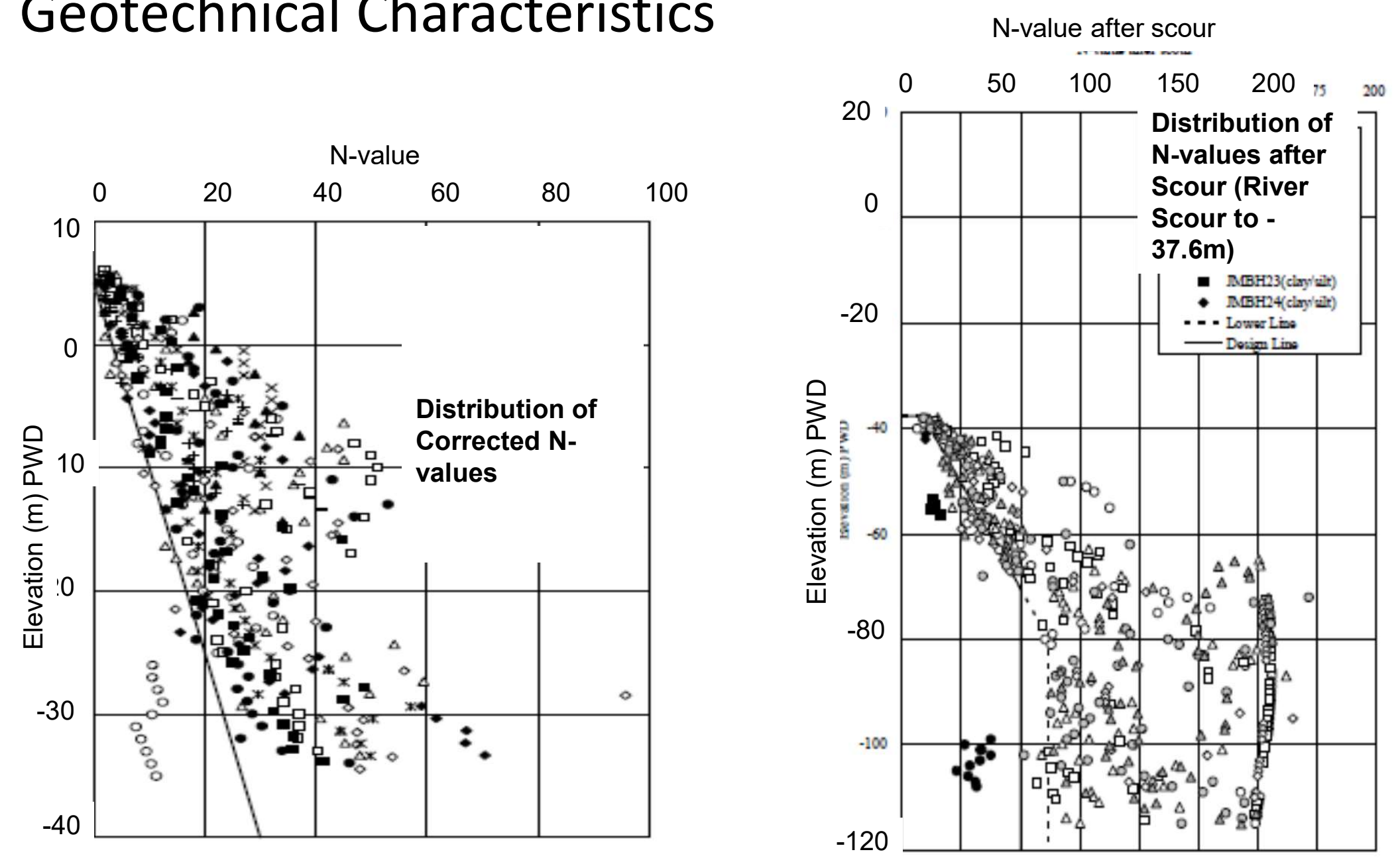
RIVER BED CONFIGURATION -The deep trenches form along right bank and render the ground increasingly more vulnerable to subaqueous slope failure due to presence of thick ( $200 \mathrm{ft}$.)

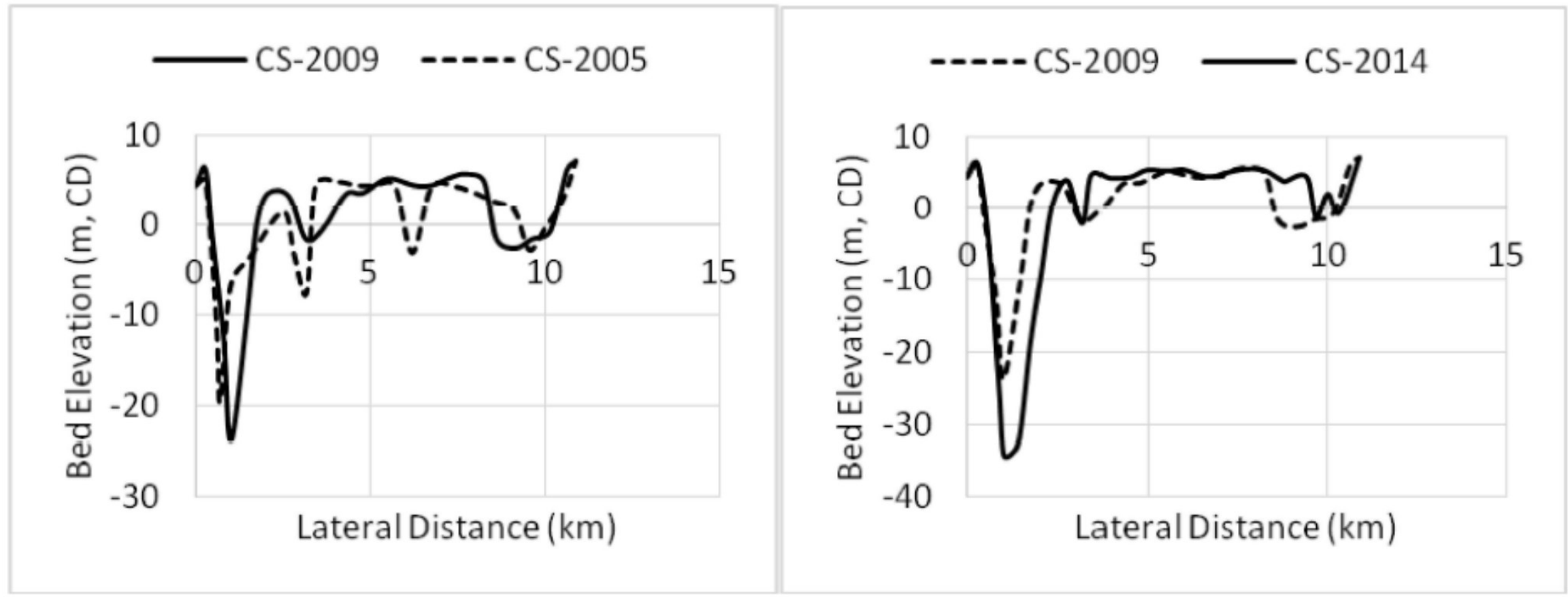

A typical cross sectional variation of Padma River at Bauria BWDB Station between 1996 and 2014 An investigation by $\underline{\text { Uddin. }}$. M J. et al (2017) at Baruria Transit station showed a dynamic behavior and deep bed level variations.

Reference: Md. Jahir Uddin, Prokashon Chakma, S.M.Abdullah Al Faruq STUDY OF WATER AND BED LEVEL VARIATION IN THE GANGES-PADMA RIVER, BANGLADESH Journal of Civil Engineering, Science and Technology 8(2):96-107 · August 2017 


\section{Findings}

Padma River remained confined within a width of 5 miles striking WW-SE trend following the margins of older alluvium and Faridpur Trough. The viver tends to a be meantdering pattern consisting of deef vertical trenches along the Naria curvature.
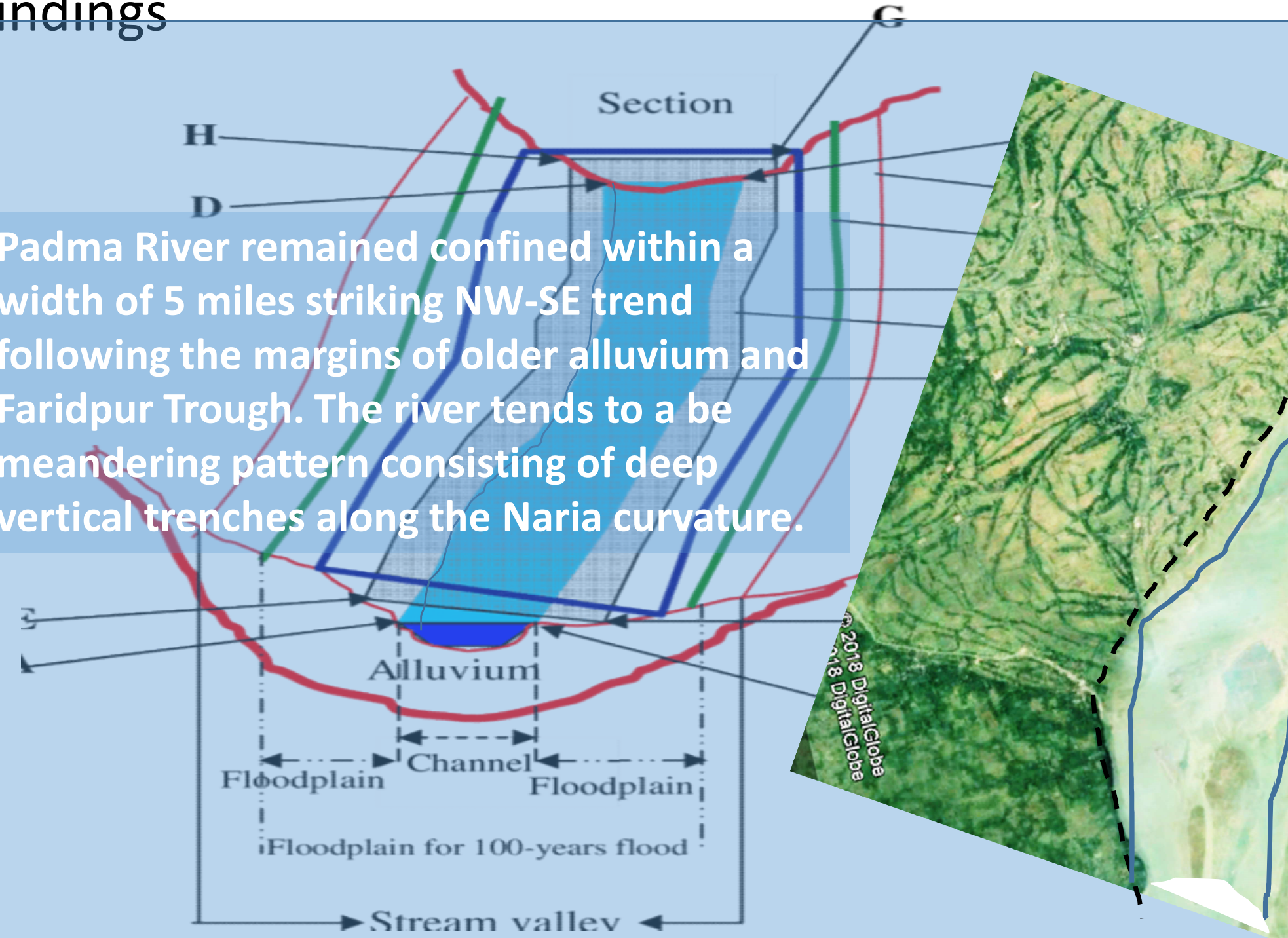


\section{Development of Live Geologic-Map System (LGMS)}

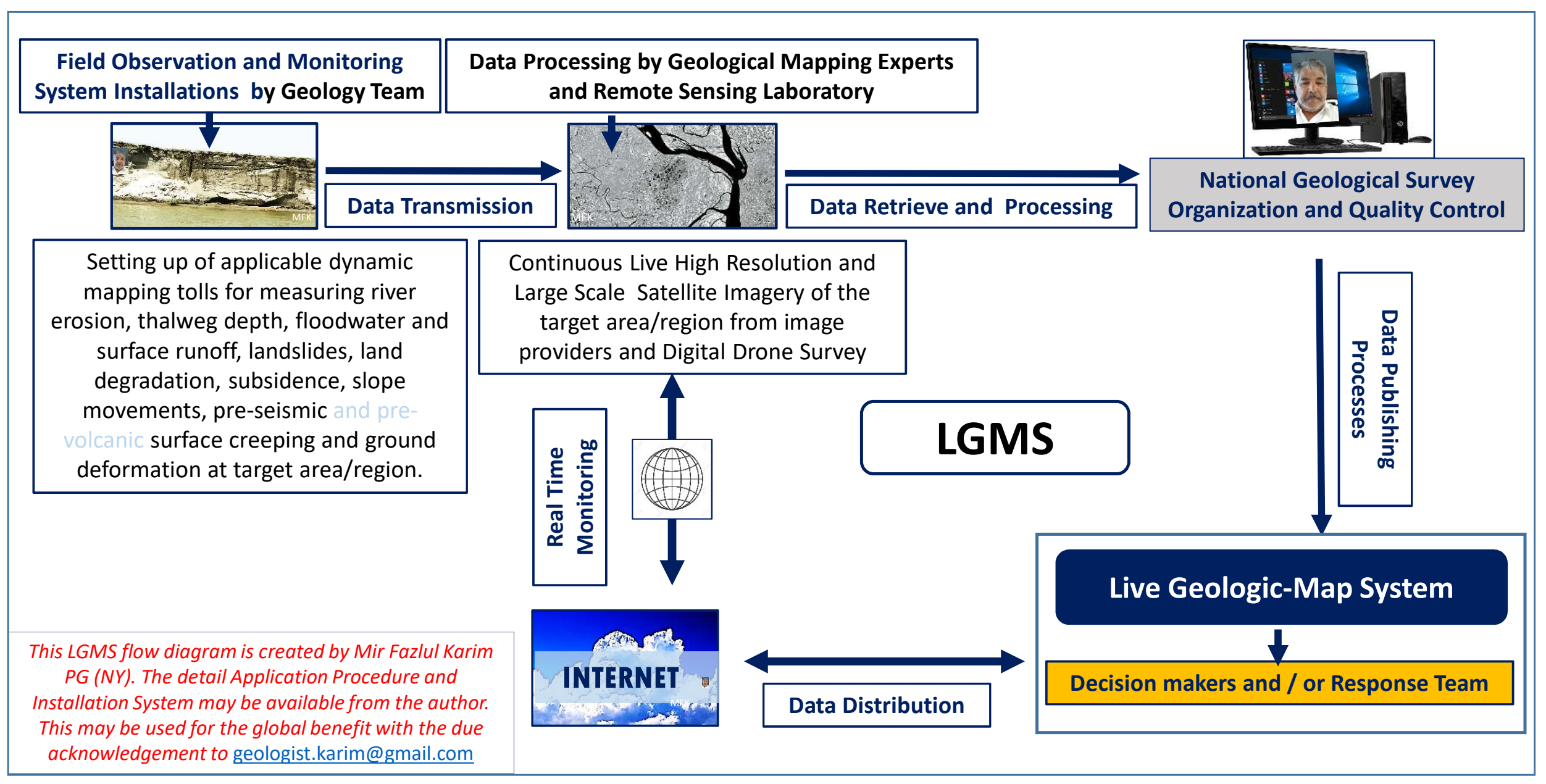




\section{CONCLUSIONS}

Padma River remained confined within a width of 5 miles striking NW-SE trend following the margins of older alluvium and Faridpur Trough.

The river tends to a meandering pattern consisting of deep vertical trenches along the Naria curvature.

The deep trenches form along right bank and render the ground increasingly more vulnerable to subaqueous slope failure due to presence of thick ( $200 \mathrm{ft}$.) alternating cross-bedded silt and micaceous fine sand of very high dilatancy and low angle of friction due to the mineralogy. 


\section{CONCLUSIONS}

The present study identifies some application of technological advancement for developing real-time engineering geological mapping systems for monitoring and managing complex river bank erosion. The authors proposes Development of Live Geologic-Map System (LGMS)

Large scale 3D engineering geological map coupled with air-borne photogrammetric and radar inferrometry methods can be applied for realtime monitoring and prediction of differential settlements, subaqueous failures and ground movement.

The point cloud maps developed using data from these systems can refine engineering geological maps for decision makers and improve the design of protective measures and sustainable engineering structures. 


\section{Live Geologic-Map System (LGMS)}

The LGMS is designed and created by Mir Fazlul Karim. The authors are interested for development, implementation and execution of the proposed system by the Geological Survey of Bangladesh. A team of geologists leaving in USA is looking forward to explore for funding from any appropriate agencies like USAID, NSF, EU, UNESCO or GoB contact: geologist.karim@gmail.com

\section{Phone: 16469328915 (USA)}




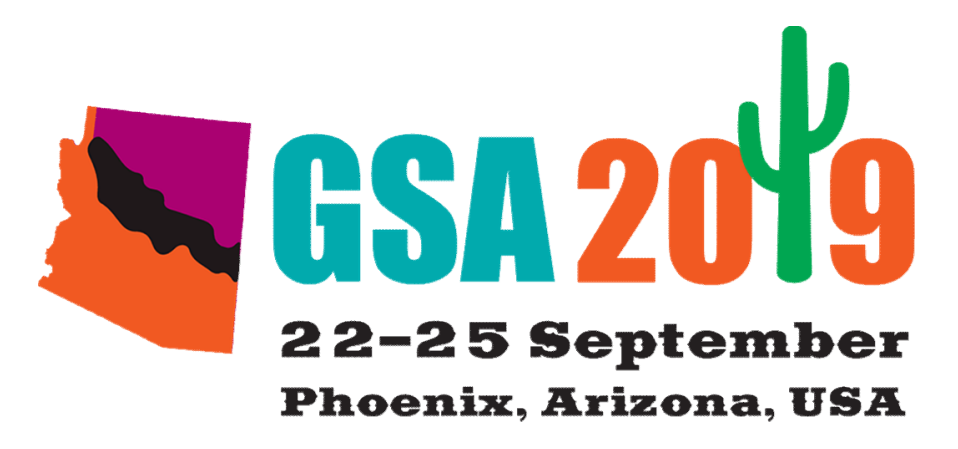

\section{THANK YOU \\ FOR YOUR KIND PATIENCE}

